\section{Glucocorticoid receptor function in hepatocytes is essential to promote postnatal body growth}

\author{
François Tronche, ${ }^{1,2,6}$ Christian Opherk, ${ }^{1,6}$ \\ Richard Moriggl, 3,6 Christoph Kellendonk, ${ }^{1}$ \\ Andreas Reimann, ${ }^{4}$ Lukas Schwake, ${ }^{1}$ \\ Holger M. Reichardt, ${ }^{1}$ Katharina Stangl, ${ }^{3}$ \\ Daniel Gau, ${ }^{1}$ Andreas Hoeflich, ${ }^{5}$ Hartmut Beug, ${ }^{3}$ \\ Wolfgang Schmid, ${ }^{1}$ and Günther Schütz ${ }^{1,7}$
}

\author{
${ }^{1}$ Molecular Biology of the Cell I, Deutsches \\ Krebsforschungszentrum, 69120 Heidelberg, Germany; \\ ${ }^{2}$ Molecular Genetics and Neurophysiology, Collège de France, \\ 75231 Paris Cedex 05, France; ${ }^{3}$ Institute of Molecular \\ Pathology, A-1030 Vienna, Austria; ${ }^{4}$ Unité Expression \\ génétique et Maladies, Département de Biologie du \\ Développement, Institut Pasteur, 75724 Paris cedex 15, \\ France; ${ }^{5}$ Lehrstuhl für Molekulare Tierzucht und \\ Haustiergenetik, Genzentrum, 81377 Muenchen, Germany
}

Mice carrying a hepatocyte-specific inactivation of the glucorticoid receptor (GR) gene show a dramatic reduction in body size. Growth hormone signaling mediated by the Stat 5 transcription factors is impaired. We show that Stat5 proteins physically interact with GR and GR is present in vivo on Stat5-dependent IGF-I and ALS regulatory regions. Interestingly, mice with a DNA-binding-deficient GR but an unaltered ability to interact with STAT5 (GR $\left.{ }^{\mathrm{dim} / \mathrm{dim}}\right)$ have a normal body size and normal levels of Stat5-dependent mRNAs. These findings strongly support the model in which GR acts as a coactivator for Stat5-dependent transcription upon GH stimulation and reveal an essential role of hepatic GR in the control of body growth.

Received September 8, 2003; revised version accepted January 27, 2004.

Glucocorticoids (GCs), which are synthesized in the adrenal cortex, act in many if not all cells of the body and play important roles in development and homeostasis. The effects of the hormone are mediated by the glucocorticoid receptor (GR) that is ubiquitously expressed and by the mineralocorticoid receptor that displays a more restricted expression profile. GR activity depends on the binding of its ligand, which is released on physiological, circadian, and stress stimuli, and thus GR participates in coordinating the organism's responses to the environment. GR can both activate and repress transcription of target genes via DNA binding to glucocorti-

[Keywords: Postnatal body growth; glucocorticoid receptor; growth hormone signaling; Stat5]

${ }^{6}$ These authors contributed equally to this work.

${ }^{7}$ Corresponding author.

E-MAIL g.schuetz@dkfz.de; FAX 49-6221-42-3470.

Article and publication are at http://www.genesdev.org/cgi/doi/10.1101/ $\operatorname{gad} .284704$. coid responsive elements (GREs) or cross-talk with other transcription factors (Beato et al. 1995; Tronche et al. 1998). Because the liver is a major target organ for GCs in control of glycogen metabolism and gluconeogenesis, we wished to address the function of hepatic GR by genetic means. As shown previously, loss of the receptor leads to lethality (Cole et al. 1995; Tronche et al. 1998). We therefore have generated cell/tissue-specific and functionselective mutations using the Cre/loxP system (Reichardt et al. 1998; Tronche et al. 1999|. To define the role of GR in hepatocytes, we expressed the recombinase in hepatocytes under the control of the albumin promoter and the albumin and $\alpha$-fetoprotein enhancers to generate mutant mice with selective inactivation of GR in these cells only (GR AlfpCre mice; Kellendonk et al. 2000). This approach allowed us to partially circumvent the perinatal lethality of GR null mutants. Surprisingly, adult mice with the hepatocyte-specific loss of GR have a severe reduction in body weight. Analysis of these mice revealed not only a novel function of GR in growth control, but also an unprecedented mode of activity.

\section{Results and Discussion}

Approximately $50 \%$ of the homozygous mutants died within $48 \mathrm{~h}$ after birth, likely due to the metabolic consequences of the hepatocyte-specific GR knock-out (data not shown). No increase in mortality was observed at later stages. Mice lacking GR in hepatocytes were indistinguishable from their littermates until 3-4 wk of age, but later displayed a severe growth deficit that was more pronounced in adult males than in females (reduction by $32 \%$ and $26 \%$ respectively; Fig. $1 \mathrm{~A})$. The growth deficit was not caused by altered fat deposition, because the body mass index was similar in both genotypes $(0.25 \pm 0.015$ and $0.25 \pm 0.007, n=8)$, but rather was due to decreased length of bones and the size of internal organs (Fig. 1B).

The characteristics of the growth deficit in mutant animals, including the similar body sizes at birth between mutant and control animals and the sexual dimorphism in adults, suggest impaired growth hormone (GH) signaling via the Jak/Stat pathway (Gouilleux et al. 1995; Tannenbaum et al. 2001; Kofoed et al. 2003). In vertebrates, body growth depends on GH produced in the anterior pituitary, which binds to the GH receptor (GHR) in peripheral organs, finally initiating a phosphorylation cascade that involves Janus Kinase2 (Jak2) and Stat5a/b proteins (signal transducer and activator of transcription 5). Dimerization of Stat5 and translocation to the nucleus results in the transcriptional activation of GHregulated genes. The suppressor of cytokine signaling-2 (SOCS-2) is thought to negatively regulate this cascade via a feedback loop (Metcalf et al. 2000). Remarkably, the short stature of GR ${ }^{\text {AlfpCre }}$ mice is very similar to that of Stat5b or Stat5ab mutant mice (Udy et al. 1997; Teglund et al. 1998; see also Fig. 4A, below). Growth impairment has also been previously observed for GH as well as GHR-deficient mice (Donahue and Beamer 1993; Zhou et al. 1997), whereas inactivation of SOCS-2 leads to gigantism (Metcalf et al. 2000).

In a first analysis, the morning serum levels of $\mathrm{GH}$ and GCs were found unchanged in mutant animals (Table 1), 
A

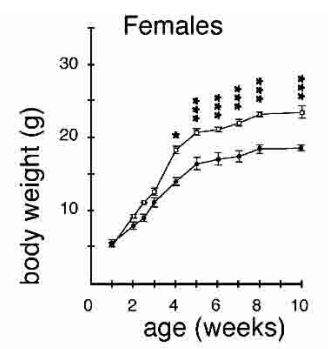

B

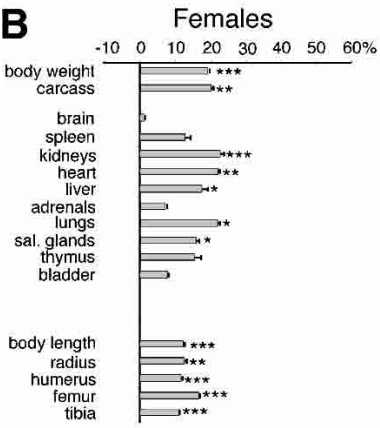

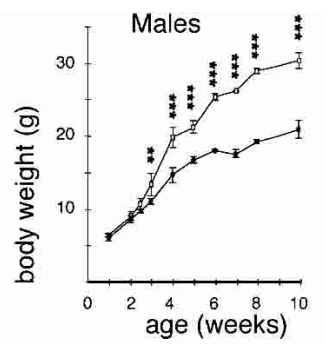

Males

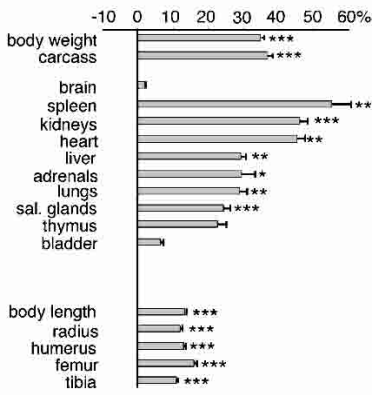

decrease in weight or length $(\%)$

Figure 1. Growth deficiency of $\mathrm{GR}^{\text {AlfpCre }}$ mice. $(A)$ Both genders of $\mathrm{GR}^{\text {AlfpCre }}$ mice show a growth deficit becoming discernible at 4-5 wk of age. The body weight of individuals from several litters was followed over a period of $10 \mathrm{wk}$. The growth curve of mutant (closed circle) and control (open square) female animals is shown in the left panel, and the corresponding growth curve of mutant (closed circle) and control (open square) males is shown in the right panel $(n=5$ to 9 per group, error bars indicate standard deviation). Control animals carrying the AlfpCre transgene but wild-type GR alleles displayed a normal growth rate (data not shown). (B) The body, carcass, organ weights, and length of bones were measured in mutant and control animals of both genders (female $n=5$ and $n=5$; male $n=4$ and $n=8$, respectively). The proportional differences as well as the level of significance (Student's $t$-test) are shown. $\left(^{\star}\right) P<0.05$; $\left(^{\star \star}\right) P<0.01$; $(* \star \star) P<0.001$.

which, together with the fact that no differences between genotypes were detected in the levels of the GHR mRNA (Fig. 2A), suggests that the defect in GH function might reside in the hepatic intracellular GH signaling cascade. We therefore quantified the mRNA abundance of GH-regulated genes in the liver of mutant and control animals and found that mRNA expression of IGF-I (Thomas et al. 1994; Woelfle et al. 2003), ALS (Ooi et al. 1998), and serine protease inhibitor 2.1 (Spi-2.1; Bergad et al. 2000) was drastically reduced (Fig. 2A). A similar decrease was observed in the major urinary protein (MUP) mRNAs whose expression is known to depend on differ-

Table 1. Serum levels of GH, corticosterone, and IGF-I in wild-type and $G R^{\text {AlfpCre }}$ mice

\begin{tabular}{lcc}
\hline & Control & GR $^{\text {AlfpCre }}$ \\
\hline $\begin{array}{l}\text { Growth hormone } \\
(\mathrm{ng} / \mathrm{mL})\end{array}$ & $1.1 \pm 0.3, n=6$ & $1.1 \pm 0.1, n=5$ \\
$\begin{array}{c}\text { Corticosterone } \\
(\mathrm{ng} / \mathrm{mL})\end{array}$ & $21 \pm 10, n=5$ & $20 \pm 12, n=4$ \\
IGF-I $(\mathrm{ng} / \mathrm{mL})$ & $699 \pm 148, n=8$ & $506 \pm 52, n=6, p<0.01$ \\
\hline
\end{tabular}

Morning levels of GH, corticosterone, and IGF-I levels were determined by radioimmunoassay.

ent strength of male and female GH pulses, which get transmitted via Stat5b in a sexual dimorphic rhythm (Davey et al. 1999; Tannenbaum et al. 2001). As expected, the mRNA levels of IGF-binding protein-3 (IGFBP-3), a GH-induced Stat5 target gene expressed only in nonparenchymal liver cells and strongly reduced in a patient carrying a missense mutation of Stat5b, remained unchanged (Fig. 2A; Domene et al. 1993; Chin et al. 1994; Kofoed et al. 2003). Therefore, IGFBP-3 serves as an internal control that restricts the origin of the growth deficit to hepatocytes only. Consistent with growth hormone resistance and the decrease in IGF-I mRNA in GR $^{\text {AlfpCre }}$ mice, circulating IGF-I levels were significantly lower in mutant animals (see Table 1). In GR ${ }^{\text {AlpCre }}$ mice, circulating levels of ALS, crucial for the bioactivity of IGF-I with which it interacts, were reduced by $>40 \%$ $(P<0.05$; data not shown; Yakar et al. 2002).

In order to identify at which level the absence of GR affects GH signaling in hepatocytes, we studied Stat5 proteins. Neither the levels of Stat5 proteins nor their phosphorylation status were significantly different in protein extracts from livers of untreated wild-type and mutant animals (data not shown). To define Stat5 activation, we followed Stat5 DNA-binding activity in wildtype mice after GH treatment, given alone or combined with dexamethasone, a GR agonist, for $60 \mathrm{~min}$ (Fig. 2B). As expected, a strong GH-dependent increase of Stat5 DNA-binding activity was observed. In the liver of GR $^{\text {AlfpCre }}$ mutant mice, neither DNA-binding activity nor Stat5 tyrosine phosphorylation were reduced, rather, extracts from mutant mice had a higher level of Stat5
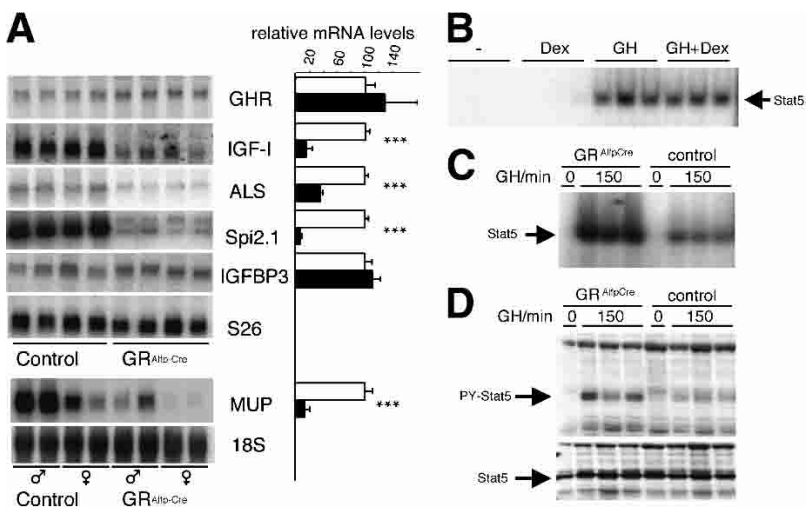

Figure 2. Impaired GH signaling in $\mathrm{GR}^{\mathrm{AlfpCre}}$ mice. $(A)$ The expression of known growth hormone-controlled genes is impaired in GR $^{\text {AlfpCre }}$ mice. Total liver RNA from GR ${ }^{\text {AlfpCre }}$ mice (black bars) and control littermates (open bars) was analyzed by Northern blotting and expression determined by quantitative determination of signal intensity. Normalization was performed relative to the S26 mRNA levels ( $n=5$ to 20 per group). In the case of MUP genes, both male and female liver mRNAs were studied because their expression is gender-dependent and normalization was performed relative to $18 \mathrm{~S}$ RNA. The mRNA levels in control livers were arbitrarily set to $100 .\left(^{\star \star \star}\right) P<0.001$. (B) Stat5 DNA-binding activity is strongly induced by GH injection into wild-type mice and is not altered by the GC agonist dexamethasone. Bandshift assays were performed with liver extracts prepared from wild-type mice before and after injection of GH and/or dexamethasone as described in Materials and Methods. DNA binding $(C)$ and phosphorylation $(D)$ of Stat5 remain

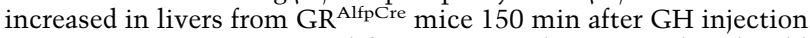
Liver extracts were prepared from untreated or GH-induced wildtype and $\mathrm{GR}^{\text {AlfpCre }}$ mice and analyzed either by bandshifts $(C)$ or by immunostaining with a phospho-tyrosine-Stat5-specific antibody $(D)$. 
phosphorylation (Fig. 2D) and a concomitant increase in DNA-binding activity (Fig. 2C). These results suggest that GR is involved in growth control by implementing the GH-dependent transcriptional activity changes in Stat5.

GR/Stat5 interaction was first documented in cell lines and suggested to be required for efficient milk protein synthesis in mammary epithelial cells following lactogenic hormone treatment (Stöcklin et al. 1996, 1997; Cella et al. 1998). Interestingly, the GR was found to copurify with Stat5 on DNA affinity columns, using Stat5 responsive DNA elements from the Spi-2.1 promoter and nuclear extracts from rat liver (Bergad et al. 2000). In addition, an interaction between Stat5 and GR in rat liver was observed by coimmunoprecipitation (Bergad et al. 2000). We confirmed this observation. As shown by reciprocal coimmunoprecipitation (Fig. 3A), Stat 5 and GR interact or coreside in a complex in mouse liver protein extracts and can be pulled down in either direction. GR interacts with both phosphorylated and unphosphorylated forms of Stat5.

To further investigate Stat5 and GR interaction, we performed chromatin immunoprecipitation (ChIP) to determine whether in vivo GR is present in protein complexes bound at the promoter of GH-regulated genes. Using a similar approach in cell culture, the investigators in a recent study showed the presence of GR on the $\alpha 2$ macroglobulin enhanceosome when Stat 3 is bound, even though no GRE is present in the enhanceosome (Lerner et al. 2003). We chose to investigate transcriptional DNA regulatory regions from two genes contributing to growth regulation, the ALS promoter and the first intron of IGF-I (Ooi et al. 1998; Yakar et al. 2002; Woelfle et al. 2003). Both genes were reported to be sensitive to GH signaling via Stat5-binding sites but to lack GREs (Fig. 3B). We injected wild-type mice with PBS or with GH and Dex. We injected GR ${ }^{\text {AlfpCre }}$ mice similarly with GH and Dex as a control. An important enrichment for both ALS and IGF-I DNA sequences was observed in treated animals using an antibody directed against Stat5 (Fig. 3C). Using an antibody directed against GR, we obtained a significant enrichment in treated control mice, demonstrating that GR is present at the level of Stat5-binding sites. The specificity of the reaction was confirmed by the lack of enrichment when $\mathrm{GR}^{\text {AlfpCre }}$ mice were used (Fig. 3C). In addition, the simultaneous presence of Stat 5 and GR on ALS and IGF-I promoters was confirmed by successive ChIP using first the anti-Stat 5 and then the anti-GR antibodies (Fig. 3D).

To strengthen the fact that Stat5-GR interaction is indeed essential for GH signaling, we analyzed growth and expression of $\mathrm{GH}$ target genes in mice that were carrying a point mutation in the GR gene $\left(\mathrm{GR}^{\mathrm{dim}}\right)$. This point mutation impairs GR homodimerization and consequently the activity of GR through binding to its cognate DNA-responsive elements. Interestingly, the mutant GR protein is able to repress AP1 and NF- $\mathrm{KB}$ activity (Reichardt et al. 1998, 2001b). Coimmunoprecipitation of Stat5ab and GR was maintained in liver protein extracts from GR ${ }^{\mathrm{dim} / \mathrm{dim}}$ mice (data not shown; Reichardt et al. 2001a). As shown in Figure 4A, GR dim/dim mice did not have a growth defect and displayed normal mRNA expression levels for IGF-I, Spi-2.1, and ALS (Fig. 4B). These data demonstrate that the activity of GR in GH signaling is independent of GR DNA binding and is most probably mediated by protein-protein interaction with Stat5. When the growth of GR ${ }^{\text {AlfpCre }}$ mice is compared
A
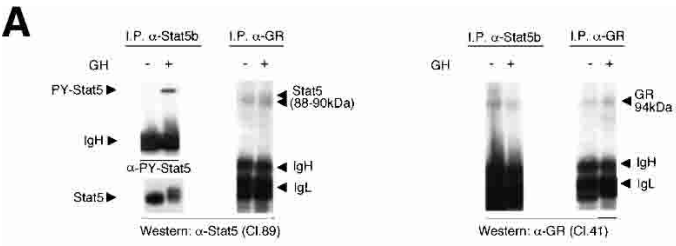

B
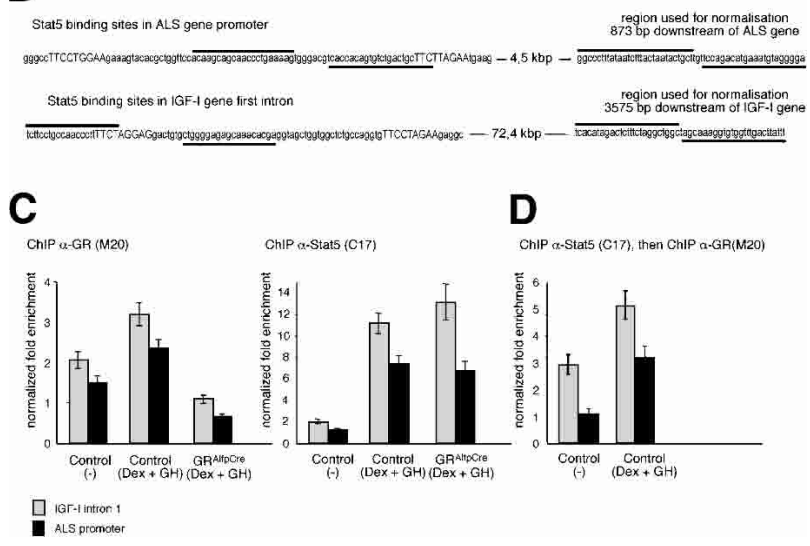

Figure 3. In vitro and in vivo interaction between Stat5 and GR. (A) Reciprocal coimmunoprecipitation using liver protein extract showed that both Stat5 and GR physically interact or coreside in a complex in vitro. Application of GH $(2 \mu \mathrm{g} / \mathrm{g}$ GH injected intraperitoneally) strongly induces phosphorylation of Stat5, but the Stat5 phosphorylation status does not significantly influence GR-Stat5 interaction. $(B)$ Nucleotide sequences of Stat5-binding sites located in the ALS promoter and the IGF-I first intron. In both cases, two distinct Stat5 DNA targets are present (bold letters). The DNA sequences of the oligonucleotides used to amplify these DNA segments, as well as the genomic region used for normalization, are indicated by a line. $(C)$ The ALS promoter and IGF-I enhancer located in the first intron of the IGF-I gene were tested in ChIP experiments in vivo; Stat5 (C17) and GR (M20) binding in control and mutant animals, treated as indicated, was analyzed. The fold enrichment for each DNA fragment on immunoprecipitation by anti-Stat 5 and anti-GR is illustrated as histograms. PCR experiments were performed in triplicate and the standard errors of these quantifications are shown as error bars. $(D)$ The same DNA regions were tested for successive ChIP experiments, first for Stat5, then for GR binding.

with the growth of Stat5 $\mathrm{ab}^{-/-}$mice, $\mathrm{GR}^{\mathrm{dim} / \mathrm{dim}}$ mice, and triple mutant mice (Fig. 4A), it is obvious that loss of DNA-binding-dependent activities of the GR in addition to loss of Stat5ab does not further impair growth. These observations strengthen the idea that Stat5 and GR act interdependently to efficiently sustain the transcription of genes essential for postnatal body growth. Altogether, these observations suggest that GR acts as a coactivator of Stat5 to promote the expression of target genes on $\mathrm{GH}$ stimulation in hepatocytes.

To follow the consequence of GR inactivation, we studied the expression of genes in livers of wild-type and GR $^{\text {AlfpCre }}$ mutant mice using Affymetrix DNA chips (Table 2). Under basal conditions, in fed and nonstressed animals, killed at the beginning of the day phase when GC levels are low, we found 26 genes (21 known genes and 5 ESTs) whose expression was reduced more than twofold in mutant mice. Among the known genes, a large fraction $(24 \%)$ are under the control of $\mathrm{GH}$ through Stat5 activation, illustrating the importance of GR for the control of liver gene expression by GH. Besides the mRNA for IGF-I, ALS, Spi-2.1, and MUP, we also found 

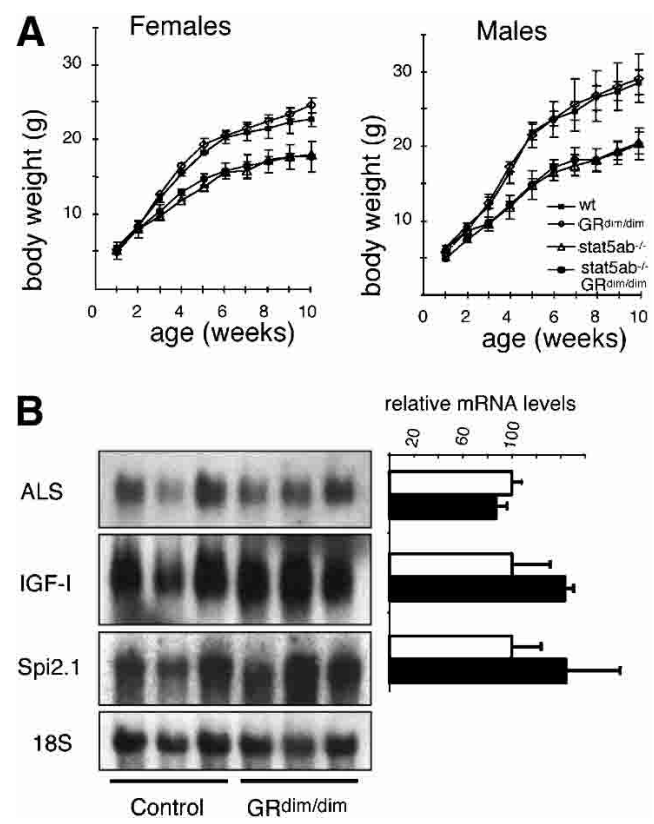

Figure 4. Growth hormone signaling is unchanged in $\mathrm{GR}^{\mathrm{dim} / \mathrm{dim}}$ mice. (A) Growth curves of wild-type (wt, filled squares), $\mathrm{GR}^{\mathrm{dim} / \mathrm{dim}}$ (diamonds), Stat5ab double mutant (triangles), and Stat5ab/GR ${ }^{\mathrm{dim} / \mathrm{dim}}$ (filled circles) triple knock-out mice. $(B)$ Total liver RNA from $\mathrm{GR}^{\mathrm{dim} / \mathrm{dim}}$ mice (black bars) and control littermates (open bars) was analyzed by Northern blotting and expression determined by quantitative determination of signal intensity, as in Figure $2 \mathrm{~A}$.

reduction in SOCS-2 mRNA, a negative regulator of Stat5 signaling whose inactivation leads to gigantism (Metcalf et al. 2000). This result strongly suggests that SOCS-2 is a GR target and likely indicates that for expression of SOCS-2 by Stat5, the GR is required, similar to IGF-I, ALS, and Spi-2.1 mRNA. In addition, this result explains the increased phosphorylation and DNAbinding activity of Stat5, on GH treatment, observed in protein extracts from liver of mutant mice when compared with control animals. We also found a decrease in the level of EGFR mRNA, in line with the observation that EGFR is up-regulated by IGF-I (Bor et al. 2000).

Surprisingly, our results demonstrate that GR function in hepatocytes is essential for body growth. The results emphasize the central role of the liver in the control of body growth, an important conclusion in the context of the somatomedin hypothesis. Several decades ago, this hypothesis postulated an essential role to the liver in control of postnatal body growth (Salmon and Daughaday 1957). The evolving concepts of this hypothesis (Le Roith et al. 2001) and the observed Stat5-GR interaction here extends the somatomedin hypothesis to insights in signaling pathway cross-talk in the liver. The growth defect described here is most probably due to impaired expression of GH-dependent target genes. The normal plasma level of $\mathrm{GH}$ and the normal expression of GHR mRNA suggest that GH signaling is impaired downstream of its receptor. The reduced expression of Stat5 target genes in $\mathrm{GR}^{\text {AlfpCre }}$, despite an enhanced activation of Stat5, and their intact expression in GR ${ }^{\text {dim/dim }}$ mice demonstrate that Stat5 action requires GR as an essential coactivator. GR or Stat5 alone is unable to sus- tain postnatal body growth. Previous studies have shown that IGF-I is essential for normal body growth and survival (Liu et al. 1993). However, mice carrying a liverspecific inactivation of IGF-I have a similar size as control animals (Sjögren et al. 1999; Yakar et al. 1999), suggesting that liver-expressed IGF-I alone is not essential for growth. But mice with a liver-specific disruption of the IGF-I gene on an $\mathrm{ALS}^{-/-}$background have a significant reduction in linear growth (Yakar et al. 2002). As shown here, the growth defect of $\mathrm{GR}^{\text {AlfpCre }}$ mice results from defective liver gene regulation of a whole set of GH-dependent genes including IGF-I, ALS, Spi-2.1, and SOCS-2. These findings underscore the significance of liver gene expression by Stat5 and GR, which are dependent on GH and GCs.

These findings also illustrate how the transcriptional activity of Stat5 that is activated by many different cytokine and growth factor signaling pathways could be engaged in the control of expression of a defined group of genes in response to the GC inducer. The requirement for specific coactivators, such as GR for GH signaling in liver cells, could participate and, as demonstrated here, dominate the response to Stat5 activation. A corollary question is to know how general the requirement of GR for Stat5 activity is in other cell types in response to Stat5 activating ligands in the presence of GCs. Besides mammary epithelial cells, in which GR is required for Stat5-mediated PRL signaling (Herrington and Carter-Su 2001), Stat5 and GR play important roles in erythrocytes (von Lindern et al. 1999; Socolovsky et al. 2001) and immune cells (Moriggl et al. 1999). Animal models disrupting or modulating Stat5-GR interaction will be essential to define their role in these systems.

In conclusion, a conditional mutagenesis approach that permits physiological dissection of GR function in living organism has furnished genetic evidence of the importance of GR-controlled liver genes as crucial growth regulators. Our findings reveal the existence of an unexpected growth-promoting role of GCs in hepatocytes. The findings provide strong in vivo evidence that the growth-promoting activity of GR is not mediated by binding to GREs, but rather through its ability to act as a coactivator, thereby synergizing with Stat5.

Table 2. Reduced expression of GH-dependent genes in

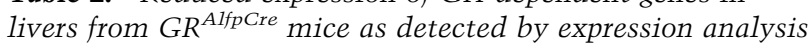
by chip hybridization

\begin{tabular}{llcc}
\hline Accession \# & Gene & Signal control & Signal GR \\
\hline D00725 & Alfre \\
L06864 & Spi2.1 & 191 & 22 \\
U88327 & SGFR & 265 & 33 \\
M17818 & MUP-1 & 279 & 85 \\
X04480 & IGF-I & 1686 & 467 \\
U66900 & ALS & 1587 & 550 \\
U15012 & GHR & 627 & 221 \\
AF009605 & PEPCK & 1023 & 730 \\
\hline
\end{tabular}

The expression of 26 genes was found reduced in mutant animals; 5 were ESTs. Among the 21 known genes, 5 (24\%) are bona fide Stat 5 targets whose expression is induced by GH. Total RNA was prepared from three pooled livers from either wild-type or mutant mice and hybridized to Affymetrix MU74v2 microchips. Expression values are indicated. 


\section{Materials and methods}

Animals

Mice with hepatocyte-specific inactivation of GR (GR ${ }^{\text {AlfpCre }}$ ) were generated by crossing mice in which both alleles of the third exon of GR were flanked by two loxP sites (GR ${ }^{\text {loxP/loxP; }}$; Tronche et al. 1999) with mice expressing the Cre recombinase under control of the albumin $/ \alpha$ fetoprotein control sequences (Kellendonk et al. 2000). GR ${ }^{\text {AlfpCre }}$ were maintained on a mixed genetic background (C57B/L6, 129SvEv, and FVB/ N). GR ${ }^{\text {dim }}$, Stat $5 \mathrm{ab}$ mutant, and intercrosses were maintained on a mixed genetic background (C57B/L6 and $129 \mathrm{SvEv}$ ) and were genotyped as previously described (Reichardt et al. 1998; Teglund et al. 1998). For some experiments, mice were injected intraperitoneally with $100 \mu \mathrm{g}$ of dexamethasone phosphate disodium salt (Sigma) and/or $2 \mu \mathrm{g} / \mathrm{g}$ recombinant $\mathrm{hGH}$ (Serono) and killed 60 or $150 \mathrm{~min}$ later. Serum and liver were shockfrozen in liquid nitrogen and stored for further use at $-80^{\circ} \mathrm{C}$.

To determine body growth, we weighed animals every week. Only animals from litters containing both mutant and control animals were included in this analysis. The body, carcass, and organ weights of adult animals were measured. The length of bones were measured on X-ray radiographies of animals. Histological analysis of paraffin sections did not reveal any alteration in the liver of mutant animals.

Blood measurements

Serum corticosterone, IGF-I, and GH were measured by commercially available kits (ICN Biochemicals, Crystal Chem, and DSL laboratories) and used according to the instructions given by the supplier. To measure morning basal levels of corticosterone, we killed animals by decapitation within $3 \mathrm{~h}$ after the beginning of the day phase. Levels of ALS were analyzed in serum samples from four animals of each genotype. Serum was separated by $12 \%$ SDS PAGE and blotted to PVDF membranes. ALS was identified by Western immunoblotting (ALS antibody 7H3-b; dilution $1 / 400$; kindly provided by Dr. C. Strasburger, Munich, Germany) and detected by the ECL system (Amersham Pharmacia) according to standard protocols.

\section{Northern blotting}

Total RNA was prepared by denaturation in guanidinium isothiocyanate. Thirty micrograms of RNA was size-separated on denaturing agarose gels and probed after transfer to nylon membranes by hybridization to ${ }^{32} \mathrm{P}$ labeled DNA probes for GHR, IGFBP-3 (kindly provided by Martin Holzenberger), ALS (NotI, XhoI fragment of IMAGE clone 998A192026), Spi2.1 (kindly provided by Alphonse Lecam), MUPs (kindly provided by Marco Pontoglio), and an oligonucleotide for IGF-I (Lee et al. 1998). Signals were quantified by PhosphorImager analysis.

Western blotting, immunoprecipitation, and bandshift assays Livers were homogenized in IP buffer and analyzed by Western blotting as described (Moriggl et al. 1999). Tyrosine phosphorylation of Stat5 was detected by a rabbit polyclonal antibody to phospho-Stat5 (\#71-6900; Zymed). For immunoprecipitation, $1 \mathrm{mg}$ of total protein extract was used per sample. Rabbit polyclonal antibodies specific against the amino acid 775-788 peptide of Stat5a (C17; Teglund et al. 1998) or against the GR N terminus (M20, Santa Cruz) were used for IP and the blots were probed with mouse monoclonal antibodies specific to Stat5 (amino acids 451649; BD Transduction Laboratories) or the GR (amino acids 176-289; BD Transduction Laboratories). Six individual mice in each group were analyzed. For bandshift assays, $30 \mu \mathrm{g}$ of extract was used with a doublestranded ${ }^{\gamma-32} \mathrm{P}$-labeled DNA probe corresponding to the Stat5-binding site of the bovine $\beta$-casein promoter. Supershift experiments with antibodies against the very last epitopes of Stat 5 were carried out to verify specificity of the Stat $5 \mathrm{~b}$ binding. Approximately $90 \%$ of the complex contains activated full-length Stat5b and the remaining $10 \%$ is full-length Stat5a (data not shown). Similar data were obtained in four individual experiments.

\section{Chromatin immunoprecipitation}

Nuclei were prepared from mouse liver as previously described (Cereghini et al. 1987); the nuclear extraction buffer contained in addition $10 \mathrm{mM} \beta$-glycerophosphate, $2 \mathrm{mM} \mathrm{Na}_{3} \mathrm{VO}_{4}$, and $2 \mathrm{mM} \mathrm{NaF}$. Nuclear pellet was resuspended in cross-linking buffer containing $15 \mathrm{mM}$ HEPES (pH 7.9), $0.34 \mathrm{M}$ sucrose, $60 \mathrm{mM} \mathrm{KCl}, 2 \mathrm{mM} \mathrm{MgCl} 2,15 \mathrm{mM} \mathrm{NaCl}, 0.15$ $\mathrm{mM} \beta$-mercaptoethanol, $0.5 \mathrm{mM}$ PMSF, $10 \mathrm{mM} \beta$-glycerophosphate, 2 $\mathrm{mM} \mathrm{Na} \mathrm{VO}_{4}, 2 \mathrm{mM} \mathrm{NaF}, 10 \mu \mathrm{g} / \mathrm{mL}$ aprotinin, and complete protein inhibitor cocktail (Roche). Formaldehyde was then added to a final concentration of $1 \%$ and nuclei were incubated for $13 \mathrm{~min}$ at $30^{\circ} \mathrm{C}$. Addition of $0.125 \mathrm{M}$ glycine (final) stopped the cross-linking reaction. Nuclei were centrifuged for $10 \mathrm{~min}$ at $10,000 \mathrm{~g}$ and $4^{\circ} \mathrm{C}$, resuspended in sonication buffer containing $50 \mathrm{mM}$ HEPES (pH 7.9), $140 \mathrm{mM} \mathrm{NaCl}, 1 \mathrm{mM}$ EDTA, $1 \%$ Triton X-100, 0.1\% Na-deoxycholate, $0.1 \%$ SDS, 0.5 mM PMSF, 10 $\mathrm{mM} \beta$-glycerophosphate, $2 \mathrm{mM} \mathrm{Na}_{3} \mathrm{VO}_{4}, 2 \mathrm{mM} \mathrm{NaF}, 10 \mu \mathrm{g} / \mathrm{mL}$ aprotinin, and complete protein inhibitor cocktail, and split into six $400-\mu \mathrm{L}$ aliquots. Chromatin aliquots were sonicated in ice water (seven times for 5 min at power output 7 with a duty cycle of $50 \%$ using the indirect sonication setup) with a W-375 sonicator (Ultrasonics Inc.) and centrifuged for $20 \mathrm{~min}$ at $21,000 \mathrm{~g}$ and $4^{\circ} \mathrm{C}$. At this point, one aliquot was saved as input sample. After centrifugation, the soluble chromatin was precleared and subjected to immunoprecipitation as previously described (Soutoglou et al. 2001). We used the anti-GR (M20) and anti-Stat5 (C17) polyclonal rabbit antibodies to immunoprecipitate the chromatin fragments. Immune complexes were collected by adsorption to protein ASepharose (Sigma). In re-ChIP assays, protein-A-Sepharose beads were washed after primary immunoprecipitation with anti-Stat5 antibody and incubated in $15 \mathrm{mM}$ DTT (final) at $37^{\circ} \mathrm{C}$ for $30 \mathrm{~min}$; the eluate was diluted 40 times with sonication buffer. Eluates were reimmunoprecipitated with anti-GR antibody as described earlier.

\section{Gene expression profiling}

Total RNA from three pooled mouse livers from 21-day-old males (GR AlfpCre and control mice) was isolated using RNeasy kits with DNase-I digestion on column (Qiagen). RNA quality was checked using the Bioanalyzer 2100 Lab-on-a-chip system (Agilent Technologies). Ten micrograms of total RNA was amplified according to the standard protocol given by the Affymetrix instructions. The transcriptomes were profiled on Affymetrix murine U74Av2 arrays according to the manufacturer's instruction. Raw data were analyzed using the MAS 5.0 version of the Affymetrix software package. Final data were calculated from three independent pools; genes with a reduced expression ratio $>2$ were considered.

\section{Quantitative PCR}

Primers were designed using PrimerExpress 2.0 software (Applied Biosystems). Quantification of precipitated DNA and input DNA fragments was carried out on an ABI PRISM 7000 sequence detection system using SYBR green in triplicates. Relative fold in vivo enrichment of DNA fragments was calculated using the following formula: $\left(\mathrm{ChIP}_{\text {target }} /\right.$ $\left.\mathrm{ChIP}_{\text {normalizer }}\right) /\left(\right.$ input $_{\text {target }} /$ input $\left._{\text {normalizer }}\right)$. We used independent normalizers for IGF-I and ALS, which are located downstream of the corresponding gene's 3'-prime end.

\section{Acknowledgments}

We are greatly indebted to Katrin Anlag and Ralf Klären for technical assistance. We thank Anton Bauer, Erich Greiner, Monique Lazar, Alphonse Lecam, Maité Corvol, Thomas Lemberger, and Brenda Stride for helpful discussions and comments and James Ihle for providing us with Stat5ab mutant mice. We are grateful to Moshe Yaniv and Marco Pontoglio for support, discussions, and advice in ChIP experiments. The Deutsche Forschungsgemeinschaft (DFG), the European Community, the Bundesministerium für Bildung und Forschung (BMBF), the Hermann von Helmholtz-Gemeinschaft Deutscher Forschungszentren (HGF), the Fonds der Chemischen Industrie, the Alexander von Humboldt-Stiftung, and the Volkswagen-Stiftung supported this work. Work in Paris was supported by an ATIPE from the CNRS.

This article is dedicated to Prof. Harald zur Hausen on the occasion of his retirement as head of the German Cancer Research Center (Deutsches Krebsforschungszentrum Heidelberg), with gratitude and appreciation for 20 years of leadership.

The publication costs of this article were defrayed in part by payment of page charges. This article must therefore be hereby marked "advertisement" in accordance with 18 USC section 1734 solely to indicate this fact.

\section{References}

Beato, M., Herrlich, P., and Schütz, G. 1995. Steroid hormone receptors: Many actors in search of a plot. Cell 83: 851-857.

Bergad, P.L., Towle, H.C., and Berry, S.A. 2000. Yin-yang 1 and glucocorticoid receptor participate in the Stat5-mediated growth hormone 
response of the serine protease inhibitor 2.1 gene. J. Biol. Chem. 275: 8114-8120.

Bor, M.V., Sorensen, B.S., Vinter-Jensen, L., Flyvbjerg, A., Pedersen, S.B., and Nexo, E. 2000. Epidermal growth factor and insulin-like growth factor I upregulate the expression of the epidermal growth factor system in rat liver. J. Hepatol. 32: 645-654.

Cella, N., Groner, B., and Hynes, N.E. 1998. Characterization of Stat5a and Stat $5 \mathrm{~b}$ homodimers and heterodimers and their association with the glucocortiocoid receptor in mammary cells. Mol. Cell. Biol. 18: 1783-1792.

Cereghini, S., Raymondiean, M., Carranca, A.G., Herbomel, P., and Yaniv, M. 1987. Factors involved in control of tissue-specific expression of albumin gene. Cell 50: 627-638.

Chin, E., Zhou, J., Dai, J., Baxter, R.C., and Bondy, C.A. 1994. Cellular localization and regulation of gene expression for components of the insulin-like growth factor ternary binding protein complex. Endocrinology 134: 2498-2504.

Cole, T.J., Blendy, J.A., Monaghan, A.P., Krieglstein, K., Schmid, W., Aguzzi, A., Fantuzzi, G., Hummler, E., Unsicker, K., and Schutz, G. 1995. Targeted disruption of the glucocorticoid receptor gene blocks adrenergic chromaffin cell development and severely retards lung maturation. Genes \& Dev. 9: 1608-1621.

Davey, H.W., Park, S.H., Grattan, D.R., McLachlan, M.J., and Waxman, D.J. 1999. STAT5b-deficient mice are growth hormone pulse-resistant. Role of STAT5b in sex-specific liver p450 expression. J. Biol. Chem. 274: 35331-35336.

Domene, H., Krishnamurthi, K., Eshet, R., Gilad, I., Laron, Z., Koch, I., Stannard, B., Cassorla, F., Roberts Jr., C.T., and LeRoith, D. 1993. Growth hormone $(\mathrm{GH})$ stimulates insulin-like growth factor-I (IGF-I) and IGF-I-binding protein-3, but not GH receptor gene expression in livers of juvenile rats. Endocrinology 133: 675-682.

Donahue, L.R. and Beamer, W.G. 1993. Growth hormone deficiency in 'little' mice results in aberrant body composition, reduced insulinlike growth factor-I and insulin-like growth factor-binding protein-3 (IGFBP-3), but does not affect IGFBP-2, -1 or -4. J. Endocrinol. 136: 91-104.

Gouilleux, F., Pallard, C., Dusanter-Fourt, I., Wakao, H., Haldosen, L.A. Norstedt, G., Levy, D., and Groner, B. 1995. Prolactin, growth hormone, erythropoietin and granulocyte-macrophage colony stimulating factor induce MGF-Stat5 DNA binding activity. EMBO J. 14: 2005-2013.

Herrington, J. and Carter-Su, C. 2001. Signaling pathways activated by the growth hormone receptor. Trends Endocrinol. Metab. 12: 252-257.

Kellendonk, C., Opherk, C., Anlag, K., Schutz, G., and Tronche, F. 2000. Hepatocyte-specific expression of Cre recombinase. Genesis 26: 151-153.

Kofoed, E.M., Hwa, V., Little, B., Woods, K.A., Buckway, C.K., Tsubaki, J., Pratt, K.L., Bezrodnik, L., Jasper, H., Tepper, A., et al. 2003. Growth hormone insensitivity associated with a STAT5b mutation. N. Engl. J. Med. 349: 1139-1147.

Le Roith, D., Bondy, C., Yakar, S., Liu, J.-L., and Butler, A. 2001. The somatomedin hypothesis: 2001. Endocr. Rev. 22: 53-74.

Lee, Y.H., Sauer, B., and Gonzalez, F.J. 1998. Laron dwarfism and noninsulin-dependent diabetes mellitus in the Hnf-1alpha knockout mouse. Mol. Cell. Biol. 18: 3059-3068.

Lerner, L., Henriksen, M.A., Zhang, X., and Darnell Jr., J.E. 2003. STAT3dependent enhanceosome assembly and disassembly: Synergy with GR for full transcriptional increase of the alpha 2-macroglobulin gene. Genes \& Dev. 17: 2564-2577.

Liu, J.P., Baker, J., Perkins, A.S., Robertson, E.J., and Efstratiadis, A. 1993. Mice carrying null mutations of the genes encoding insulin-like growth factor I (Igf-1) and type 1 IGF receptor (Igf1r). Cell 75: 59-72.

Metcalf, D., Greenhalgh, C.J., Viney, E., Willson, T.A., Starr, R., Nicola, N.A., Hilton, D.J., and Alexander, W.S. 2000. Gigantism in mice lacking suppressor of cytokine signalling-2. Nature 405: 1069-1073.

Moriggl, R., Sexl, V., Piekorz, R., Topham, D., and Ihle, J.N. 1999. Stat5 activation is uniquely associated with cytokine signaling in peripheral T cells. Immunity 11: 225-230.

Ooi, G.T., Hurst, K.R., Poy, M.N., Rechler, M.M., and Boisclair, Y.R. 1998. Binding of STAT5a and STAT5b to a single element resembling a gamma-interferon-activated sequence mediates the growth hormone induction of the mouse acid-labile subunit promoter in liver cells. Mol. Endocrinol. 12: 675-687.

Reichardt, H.M., Kaestner, K.H., Wessely, O., Tuckermann, J., Angel, P., Kretz, O., Bock, R., Schmid, W., Herrlich, P., and Schütz, G. 1998. DNA binding of the glucocorticoid receptor is not essential for survival. Cell 93: 1-20.
Reichardt, H.M., Horsch, K., Gröne, H.-J., Kolbus, A., Beug, H., Hynes, N., and Schütz, G. 2001a. Mammary gland development and lactation are controlled by different glucocorticoid receptor activities. Eur. J. Endocrinol. 145: 519-527.

Reichardt, H.M., Tuckermann, J.P., Göttlicher, M., Vujic, M., Weih, F., Angel, P., Herrlich, P., and Schütz, G. 2001b. Repression of inflammatory responses in the absence of DNA-binding by the glucocorticoid receptor. EMBO J. 20: 7168-7173.

Salmon, W.D. and Daughaday, W.H. 1957. A hormonally controlled serum factor which stimulates sulfate incorporation by cartilage in vitro. J. Lab. Clin. Med. 49: 825-836.

Sjögren, K., Liu, J.-L., Blad, K., Skrtic, S., Vidal, O., Wallenius, V., LeRoith, D., Törnell, J., Isaksson, O.G.P., Jansson, J.-O., et al. 1999. Liver-derived insulin-like growth factor I (IGF-I) is the principal source of IGF-I in blood but is not required for postnatal body growth in mice. Proc. Natl. Acad. Sci. 96: 7088-7092.

Socolovsky, M., Nam, H., Fleming, M.D., Haase, V.H., Brugnara, C., and Lodish, H.F. 2001. Ineffective erythropoiesis in Stat5a(-/-) mice due to decreased survival of early erythroblasts. Blood 98: 3261-3273.

Soutoglou, E., Viollet, B., Vaxillaire, M., Yaniv, M., Pontoglio, M., and Talianidis, I. 2001. Transcription factor-dependent regulation of CBP and P/CAF histone acetyltransferase activity. EMBO J. 20: 1984-1992.

Stöcklin, E., Wissler, M., Gouilleux, F., and Groner, B. 1996. Functional interactions between Stat 5 and the glucocorticoid receptor. Nature 383: $726-728$.

Stöcklin, E., Wissler, M., Moriggl, R., and Groner, B. 1997. Specific DNA binding of Stat5, but not of glucocorticoid receptor, is required for their functional cooperation in the regulation of gene transcription. Mol. Cell. Biol. 17: 6708-6716.

Tannenbaum, G.S., Choi, H.K., Gurd, W., and Waxman, D.J. 2001. Temporal reationship between the sexually dimorphic spontaneous GH secretory profiles and hepatic STAT5 activity. Endocrinology 142: 4599-4606.

Teglund, S., McKay, C., Schuetz, E., van Deursen, J.M., Stravopodis, D. Wang, D., Brown, M., Bodner, S., Grosveld, G., and Ihle, J.N. 1998. Stat5a and Stat5b proteins have essential and nonessential, or redundant, roles in cytokine responses. Cell 93: 841-850.

Thomas, M.J., Kikuchi, K., Bichell, D.P., and Rotwein, P. 1994. Rapid activation of rat insulin-like growth factor-I gene transcription by growth hormone reveals no alterations in deoxyribonucleic acid-protein interactions within the major promoter. Endocrinology 135: 1584-1592.

Tronche, F., Kellendonk, C., Reichardt, H.M., and Schütz, G. 1998. Genetic dissection of glucocorticoid receptor function in mice. Curr. Opin. Genet. Dev. 8: 532-538

Tronche, F., Kellendonk, C., Kretz, O., Gass, P., Anlag, K., Orban, P.C., Bock, R., Klein, R., and Schutz, G. 1999. Disruption of the glucocorticoid receptor gene in the nervous system results in reduced anxiety. Nat. Genet. 23: 99-103.

Udy, G.B., Towers, R.P., Snell, R.G., Wilkins, R.J., Park, S.-H., Ram, P.A., Wayman, D.J., and Davey, H.W. 1997. Requirement of STAT5b for sexual dimorphism of body growth rates and liver gene expression. Proc. Natl. Acad. Sci. 94: 7239-7244.

von Lindern, M., Zauner, W., Mellitzer, G., Steinlein, P., Fritsch, G., Huber, K., Lowenberg, B., and Beug, H. 1999. The glucocorticoid receptor cooperates with the erythropoietin receptor and c-Kit to enhance and sustain proliferation of erythroid progenitors in vitro. Blood 94: 550-559.

Woelfle, J., Chia, D.J., and Rotwein, P. 2003. Mechanisms of growth hormone $(\mathrm{GH})$ action. Identification of conserved Stat 5 binding sites that mediate GH-induced insulin-like growth factor-I gene activation. J. Biol. Chem. 278: 51261-51266.

Yakar, S., Liu, J.-L., Stannard, B., Butler, A., Accili, D., Sauer, B., and LeRoith, D. 1999. Normal growth and development in the absence of hepatic insulin-like growth factor I. Proc. Natl. Acad. Sci. 96: 7324-7329.

Yakar, S., Rosen, C.J., Beamer, W.G., Ackert-Bicknell, C.L., Wu, Y., Liu, J.L., Ooi, G.T., Setser, J., Frystyk, J., Boisclair, Y.R., et al. 2002. Circulating levels of IGF-1 directly regulate bone growth and density. $J$. Clin. Invest. 110: 771-781.

Zhou, Y., Xu, B.C., Maheshwari, H.G., He, L., Reed, M., Lozykowski, M., Okada, S., Cataldo, L., Coschigamo, K., Wagner, T.E., et al. 1997. A mammalian model for Laron syndrome produced by targeted disruption of the mouse growth hormone receptor/binding protein gene / the Laron mouse). Proc. Nat1. Acad. Sci. 94: 13215-13220. 


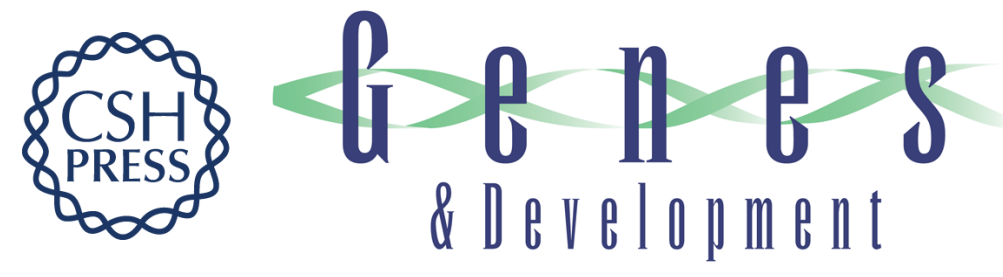

\section{Glucocorticoid receptor function in hepatocytes is essential to promote postnatal body growth}

François Tronche, Christian Opherk, Richard Moriggl, et al.

Genes Dev. 2004, 18:

Access the most recent version at doi:10.1101/gad.284704

References This article cites 41 articles, 18 of which can be accessed free at: http://genesdev.cshlp.org/content/18/5/492.full.html\#ref-list-1

License

Email Alerting

Receive free email alerts when new articles cite this article - sign up in the box at the top Service right corner of the article or click here.

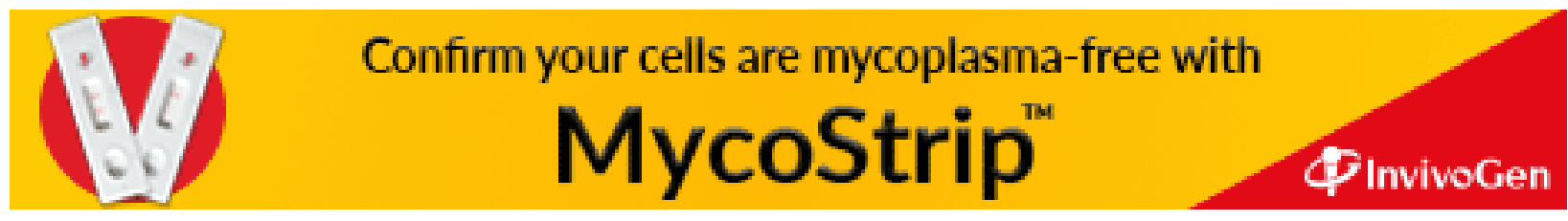

